\title{
THE CADDISFLY FAUNA (INSECTA: TRICHOPTERA) OF THE LLAP RIVER CATCHMENT, REPUBLIC OF KOSOVO
}

\author{
Halil Ibrahimi ${ }^{1, *}$ \& Nexhip Sejdiu ${ }^{2}$ \\ ${ }^{1}$ Department of Biology, Faculty of Mathematical and Natural Sciences, University of Prishtina, \\ "Mother Theresa" p.n., 10000 Prishtina, Republic of Kosovo
}

2Secondary School “Aleksandër Gjuvani”, 11000 Podujevë, Republic of Kosovo

Ibrahimi , H. \& Sejdiu, N.: The caddisfly fauna (Insecta: Trichoptera) of the Llap River catchment, Republic of Kosovo. Nat. Croat. Vol. 27, No. 2, 293-304, 2018, Zagreb.

We sampled Trichoptera monthly, from May to November 2013, at nine localities of the Llap River catchment in Kosovo. A total of 651 specimens belonging to 14 families and 37 species were found. There is a clear pattern of seasonality in the abundance and number of species with the highest number of species and specimens collected during the summer period.

The genus Ithytrichia, which is according to the current knowledge rather rare in the Balkan Peninsula, is reported from Kosovo for the first time. Two species are first records for the Kosovo caddisfly fauna: Crunoecia irrorata and Ithytrichia lamellaris. Previously, both species had been rarely sampled in South-eastern Europe. Additionally, several other endemic or rare species of the Balkan Peninsula were collected during this investigation: Rhyacophila loxias, Synagapetus iridipennis, Polycentropus excisus, Drusus botosaneanui, Annitella triloba, Odontocerum hellenicum and Adicella balcanica.

Key words: Trichoptera, Kosovo, Balkan Peninsula, rare species, endemic species, Ithytrichia lamellaris, Crunoecia irrorata.

Ibrahimi , H. \& Sejdiu, N.: Fauna tulara (Insecta: Trichoptera) sliva rijeke Llap, Republika Kosovo. Nat. Croat. Vol. 27, No. 2, 293-304, 2018, Zagreb.

U razdoblju od svibnja do studenog 2013. mjesečno smo prikupljali faunu Trichoptera na 9 lokaliteta sliva rijeke Llap na Kosovu. Prikupljen je ukupno 651 primjerak iz 14 porodica i 37 vrsta. Utvrđen je jasni uzorak sezonalnosti u brojnosti i broju vrsta u odnosu na najveći broj vrsta i primjeraka prikupljenih tijekom ljetnog perioda.

Rod Ithytrichia, prema sadašnjim saznanjima prilično rijedak na Balkanskom poluotoku, pronađen je na Kosovu po prvi puta. Dvije vrste sup o prvi puta zabilježene za faunu Kosova: Crunoecia irrorata i Ithytrichia lamellaris. Dosad su obje vrste bile rijetko prikupljane u jugoistočnoj Europi. Osim toga u ovom israživanju prikupljeno je još nekoliko drugih endemskih i rijetkih vrsta za Balkanski poluotok: Rhyacophila loxias, Synagapetus iridipennis, Polycentropus excisus, Drusus botosaneanui, Annitella triloba, Odontocerum hellenicum i Adicella balcanica.

Ključne riječi: Trichoptera, Kosovo, Balkanski poluotok, rijetke vrste, endemi, Ithytrichia lamellaris, Crunoecia irrorata.

*corresponding author's e-mail: halil.ibrahimi@uni-pr.edu 


\section{INTRODUCTION}

Few efforts have been made in the Llap River basin regarding the taxonomy and ecology of aquatic insects, including caddisflies. Some previous scarce data on the seasonal dynamics of macroinvertebrates of the Llap River lacked taxonomic importance due to the difficulties in properly identifying caddisfly larvae up to the species level. Patterns of emergence, abundance and longevity of flight period of aquatic insects are important aspects of understanding the way a particular freshwater ecosystem functions (Corbet, 1964; Grant \& Mackay, 1969; DeWalt et al., 1994). These parameters explain the way resources are allocated and how the competition of functionally similar or close species works.

Anthropogenic disturbance of freshwater ecosystems is one of the largest continuous environmental problems in Kosovo and thus quantification of aquatic biodiversity is an important measure to document the level of this environmental disturbance (e.g. IBRAHIMI et al., 2012a, 2014b). Documenting the biodiversity and ecology of caddisflies is an important tool in proper water quality biomonitoring procedures where pollution tolerance, habitat affinity and trophic functional groups become relevant only if associated with precise taxonomic data (Houghton, 2002).

This investigation is the first systematic survey of the caddisfly fauna of the Llap River catchment. The goal of this paper is to contribute to the faunistic list of caddisflies of Kosovo, including some ecological information such as abundance and phenology. In addition to this, the goal is also to give new information on the distribution of some endemic and rare species of the Balkan Peninsula.

\section{MATERIAL AND METHODS}

\section{Study area}

The Llap River is located in the north-eastern part of the Republic of Kosovo. It originates from several sources from the Kopaonik Mountains close to the Pilatovica and Belastena peaks on the state border between Kosovo and Serbia. The river passes through the Podujevë, Prishtinë and Vushtrri municipalities and discharges into the Sitnica River at Stanofc i Poshtëm village, southwest of the capital Prishtina. The total length of the river is about $70 \mathrm{~km}$. Adult caddisfly specimens were collected at nine localities of the upper and middle reach of the Llap River (Tab. 1, Figs 1 \& 2). One sampling station (S8) is located at a spring area of the tributary of the Llap River named Vrella e Revuçit spring, an additional two stations are located in tributaries of the Llap River (L5 and L7), while the remaining 6 sampling stations are located at the main flow of the Llap River (Fig. 1).

\section{Data sampling and processing}

Adult caddisfly specimens were collected monthly from May to November 2013. Sampling was conducted using entomological nets during the day and UV pyramid type light traps during the night. The pyramid light traps were placed on stream banks and operated for one hour and fifteen minutes immediately after the dusk. Nights with full moon were avoided for UV sampling, due to the low number of sampled specimens during such times. Collected samples were preserved in $80 \%$ ethanol. The specimens were identified under a stereomicroscope with determination keys from MALICKY (2004) and KumAnski $(1985,1988)$. 
Tab. 1. Locality data for the 9 sampling stations in the Llap River catchment where caddisflies were collected.

\begin{tabular}{|c|l|l|l|l|}
\hline Code & Sampling Stations & Latitude $^{\circ} \mathrm{N}$ & Longitude $^{\circ} \mathrm{E}$ & Altitude $\mathrm{m}$ \\
\hline L1 & Marincë village & $43^{\circ} 06^{\prime} 99$ & $21^{\circ} 02^{\prime} 18$ & 982 \\
\hline L2 & Murgull village & $43^{\circ} 05^{\prime} 50$ & $21^{\circ} 02^{\prime} 12$ & 972 \\
\hline L3 & Tërnavicë village & $43^{\circ} 06^{\prime} 99$ & $21^{\circ} 02^{\prime} 18$ & 880 \\
\hline L4 & Zhiti village & $43^{\circ} 03^{\prime} 10$ & $21^{\circ} 04^{\prime} 48$ & 845 \\
\hline L5 & Tributary in Reçicë village & $43^{\circ} 06^{\prime} 65$ & $21^{\circ} 03^{\prime} 12$ & 890 \\
\hline L6 & Pollatë village & $43^{\circ} 03^{\prime} 00$ & $21^{\circ} 07^{\prime} 25$ & 820 \\
\hline L7 & Tributary in Kaçandoll village & $42^{\circ} 96^{\prime} 66$ & $21^{\circ} 07^{\prime} 02$ & 1112 \\
\hline L8 & Vrella e Revuçit spring & 42.995444 & 21.107225 & 789 \\
\hline L9 & Zakutë village & 42.984194 & 21.151143 & 670 \\
\hline
\end{tabular}

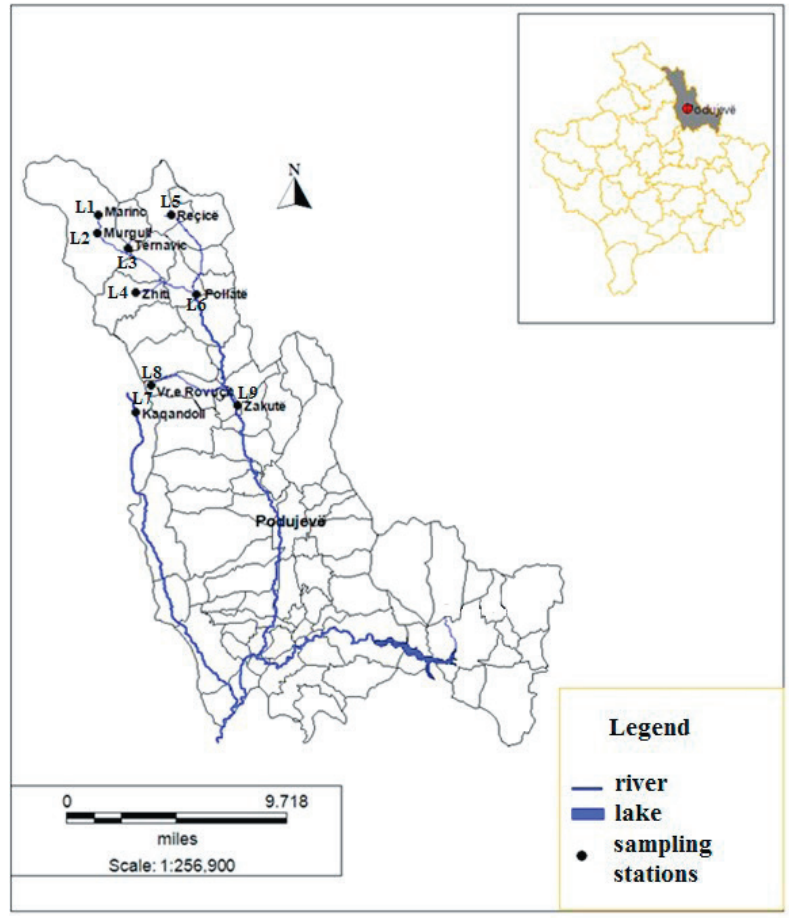

Fig. 1. Podujevë Municipality with nine sampling stations in the Llap River catchment: L1 - Marincë, L2 - Murgull, L3 - Tërnavicë, L4 - Zhiti, L5 - Reçicë, L6 - Pollatë, L7 - Kaçandoll, L8 - Revuqë, L9 Zakutë.

All specimens were identified up to the species level, with the exception of Hydropsyche Pictet, 1834 females, which are identified only up to the generic level. The collection is deposited at the Laboratory of Zoology of the Faculty of Mathematics and Natural Sciences, University of Prishtina, Republic of Kosovo. Systematic presentation was done according to Morse (2017).

Species diversity, uniformity and richness were statistically analyzed using the ComEcoPac software package (DrozD, 2010). This software includes amongst other the following indices and parameters: number of specimens, number of species, Tischler's 

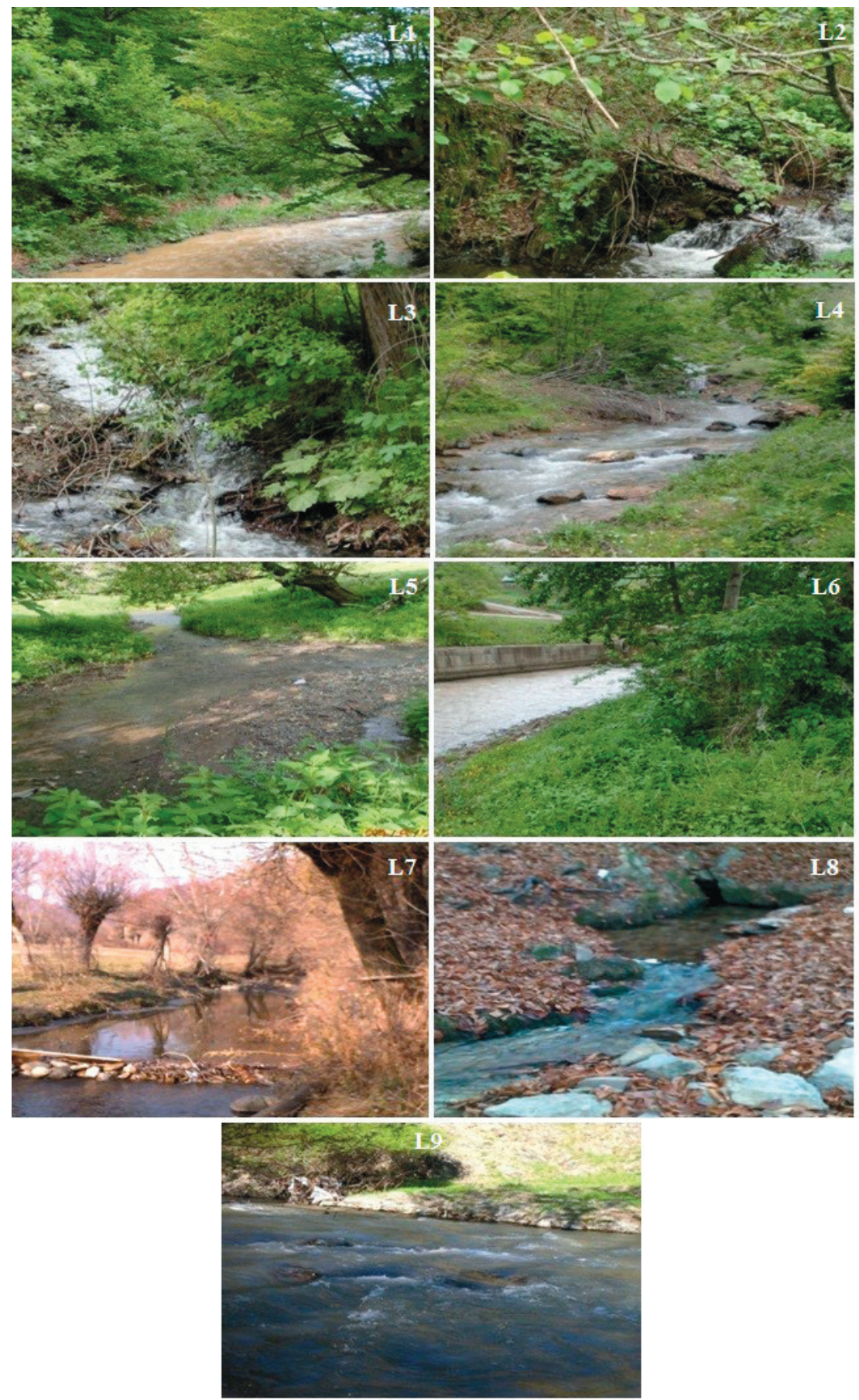

Fig. 2. Nine sampling stations in the Llap River catchment where caddisflies were collected from May to November 2013: L1 - Marincë, L2 - Murgull, L3 - Tërnavicë, L4 - Zhiti, L5 - Reçicë, L6 - Pollatë, L7 - Kaçandoll, L8 - Revuqë, L9 - Zakutë. 
dominance classes (TISCHLER, 1949) and associated abundance data, number of singletons, doubletons and tripletons, Shannon-Wiener Index of diversity, Simpson Index of Diversity and Species Richness Estimator Chao1 with its variance.

\section{RESULTS}

During this investigation a total of 651 adult specimens (446 females and 204 males) were collected, belonging to 37 species, 22 genera and 14 families (Tabs 2, 3, 4). The highest number of species was found at L7 and L2. The lowest number of species was found in the middle reach of the Murgull River (L6) and Vrellë e Revuqit tributary (L8). The highest number of specimens was found at L7 (216 specimens) and the lowest number at L3 (17 only).

Tab. 2. Abundance of observed caddisfly species at 9 sampling stations in the Llap River catchment. Full names of sampling stations are listed in Tab. 1.

\begin{tabular}{|c|c|c|c|c|c|c|c|c|c|}
\hline \multirow{2}{*}{ Species } & \multicolumn{9}{|c|}{ Sampling stations } \\
\hline & L1 & $\mathrm{L} 2$ & L3 & L4 & L5 & L6 & L7 & L8 & L9 \\
\hline Rhyacophila armeniaca Guerin-Meneville, 1834 & 0 & 1 & 1 & 6 & 0 & 0 & 6 & 0 & 0 \\
\hline Rhyacophila fasciata Hagen, 1859 & 0 & 0 & 2 & 4 & 5 & 0 & 13 & 0 & 1 \\
\hline Rhyacophila loxias Schmid, 1970 & 2 & 2 & 1 & 1 & 0 & 0 & 5 & 0 & 0 \\
\hline Rhyacophila nubila Zetterstedt, 1840 & 0 & 1 & 0 & 0 & 0 & 2 & 3 & 0 & 8 \\
\hline Rhyacophila obliterata McLachlan, 1863 & 5 & 0 & 0 & 0 & 0 & 0 & 1 & 0 & 0 \\
\hline Rhyacophila polonica McLachlan, 1879 & 0 & 1 & 3 & 4 & 3 & 0 & 5 & 0 & 0 \\
\hline Rhyacophila tristis Pictet, 1834 & 1 & 7 & 0 & 1 & 0 & 0 & 0 & 4 & 0 \\
\hline Agapetus laniger Pictet, 1834 & 0 & 0 & 0 & 0 & 0 & 0 & 0 & 0 & 2 \\
\hline Synagapetus iridipennis McLachlan, 1879 & 0 & 2 & 0 & 0 & 0 & 0 & 0 & 3 & 0 \\
\hline Hydroptila forcipata (Eaton, 1873 ) & 0 & 0 & 0 & 0 & 0 & 0 & 30 & 0 & 10 \\
\hline Ithytrichia lamellaris (Eaton, 1873 ) & 0 & 0 & 0 & 0 & 0 & 0 & 0 & 0 & 66 \\
\hline Philopotamus montanus (Donovan, 1913) & 1 & 6 & 0 & 0 & 0 & 0 & 0 & 1 & 0 \\
\hline Philopotamus variegatus (Scopoli, 1763) & 0 & 1 & 0 & 0 & 0 & 0 & 0 & 0 & 0 \\
\hline Wormaldia occipitalis (Pictet, 1834) & 1 & 1 & 0 & 0 & 0 & 0 & 0 & 4 & 0 \\
\hline Hydropsyche instabilis (Curtis, 1834) & 15 & 5 & 2 & 4 & 5 & 1 & 12 & 0 & 0 \\
\hline Hydropsyche sp. females & 24 & 2 & 3 & 8 & 13 & 31 & 39 & 0 & 8 \\
\hline Hydropsyche saxonica McLachlan, 1844 & 0 & 0 & 0 & 2 & 0 & 0 & 0 & 0 & 0 \\
\hline Polycentropus excisus Klapalek, 1894 & 0 & 0 & 0 & 0 & 0 & 0 & 2 & 0 & 0 \\
\hline Lype reducta (Hagen, 1868) & 0 & 1 & 0 & 0 & 0 & 0 & 0 & 4 & 0 \\
\hline Psychomyia pusilla (Fabricius, 1781) & 0 & 0 & 0 & 0 & 0 & 1 & 7 & 7 & 46 \\
\hline Tinodes rostocki McLachlan, 1878 & 0 & 2 & 2 & 0 & 0 & 0 & 7 & 0 & 0 \\
\hline Tinodes unicolor (Pictet, 1834) & 0 & 0 & 0 & 2 & 0 & 0 & 0 & 0 & 0 \\
\hline Brachycentrus maculatus (Fourcroy, 1785) & 0 & 0 & 0 & 0 & 0 & 0 & 0 & 0 & 1 \\
\hline Drusus botosaneanui Kumanski, 1968 & 1 & 1 & 0 & 5 & 0 & 0 & 3 & 0 & 0 \\
\hline Halesus digitatus (Schrank, 1781) & 4 & 9 & 0 & 1 & 12 & 1 & 1 & 0 & 0 \\
\hline Potamophylax latipennis (Curtis, 1834) & 8 & 1 & 1 & 1 & 7 & 0 & 1 & 0 & 0 \\
\hline Annitella triloba Marinković-Gospodnetić, 1955 & 1 & 0 & 0 & 0 & 0 & 0 & 0 & 0 & 0 \\
\hline Stenophylax meridiorietalis Malicky, 1982 & 0 & 0 & 1 & 0 & 0 & 0 & 0 & 0 & 0 \\
\hline Silo piceus (Brauer, 1857 ) & 0 & 0 & 0 & 0 & 1 & 0 & 75 & 0 & 0 \\
\hline Lepidostoma basale (Kolenati, 1848) & 0 & 0 & 0 & 1 & 1 & 5 & 0 & 0 & 2 \\
\hline Crunoecia irrorata (Curtis, 1834) & 1 & 0 & 0 & 0 & 0 & 0 & 0 & 0 & 0 \\
\hline Adicella balcanica Botosaneanu \& Novak, 1965 & 0 & 0 & 0 & 0 & 0 & 1 & 0 & 0 & 0 \\
\hline Athripsodes bilineatus (Linnaeus, 1758) & 0 & 0 & 0 & 0 & 0 & 0 & 4 & 0 & 0 \\
\hline Mystacides niger (Linnaeus, 1758) & 0 & 0 & 0 & 0 & 1 & 0 & 0 & 0 & 0 \\
\hline Odontocerum hellenicum Malicky, 1972 & 0 & 1 & 0 & 0 & 4 & 0 & 1 & 2 & 0 \\
\hline Oecismus monedula (Hagen, 1859) & 1 & 1 & 1 & 1 & 2 & 0 & 1 & 0 & 0 \\
\hline Sericostoma flavicorne Scheider, 1845 & 0 & 0 & 0 & 0 & 0 & 1 & 0 & 0 & 1 \\
\hline
\end{tabular}


Tab. 3. Abundance and Diversity Indices for caddisflies at nine sampling stations of the Llap River catchment: $\mathrm{S}$ - number of species, $\mathrm{N}$ - number of specimens, $\mathrm{SE}$ - number of eudominant species, SD - number of dominant species, SSd - number of subdominant species, SR - number of recendent species, $\mathrm{SSr}$ - number of subrecendent species, NE - abundance of eudominant species, ND - abundance of dominant species, NSd - abundance of subdominant species, NR - abundance of recendent species, $\mathrm{NSr}$ - abundance of subrecendent species, F1 - number of singletons, F2 - number of doubletons, F3 number of tripletons, $\mathrm{H}^{\prime}$ - Shannon-Wiener Index of Diversity, D - Simpsons Index, SChao1 - Species Richness Estimator (Chao1), Var(SChao1) - Variance of the Estimated Richness. Full names of sampling stations are listed in Tab. 1.

\begin{tabular}{|l|c|c|c|c|c|c|c|c|c|}
\hline \multirow{2}{*}{ Indices } & \multicolumn{9}{c|}{ Sampling stations } \\
\cline { 2 - 11 } & L1 & L2 & L3 & L4 & L5 & L6 & L7 & L8 & L9 \\
\hline $\mathrm{S}$ & 13 & 18 & 10 & 14 & 11 & 8 & 19 & 7 & 10 \\
\hline $\mathrm{N}$ & 65 & 45 & 17 & 41 & 54 & 43 & 216 & 25 & 145 \\
\hline $\mathrm{S}_{\mathrm{E}}$ & 3 & 4 & 5 & 3 & 3 & 2 & 3 & 5 & 2 \\
\hline $\mathrm{S}_{\mathrm{D}}$ & 2 & 0 & 5 & 3 & 4 & 0 & 2 & 1 & 3 \\
\hline $\mathrm{S}_{\mathrm{S}} \mathrm{d}$ & 1 & 14 & 0 & 8 & 1 & 6 & 5 & 1 & 0 \\
\hline $\mathrm{S}_{\mathrm{R}}$ & 7 & 0 & 0 & 0 & 3 & 0 & 3 & 0 & 2 \\
\hline $\mathrm{S}_{\mathrm{S}} \mathrm{r}$ & 0 & 0 & 0 & 0 & 0 & 0 & 6 & 0 & 3 \\
\hline $\mathrm{N}_{\mathrm{E}}$ & 47 & 27 & 12 & 19 & 32 & 36 & 144 & 22 & 112 \\
\hline $\mathrm{N}_{\mathrm{D}}$ & 9 & 0 & 5 & 12 & 17 & 0 & 25 & 2 & 26 \\
\hline $\mathrm{N}_{\mathrm{S}} \mathrm{d}$ & 2 & 18 & 0 & 10 & 2 & 7 & 30 & 1 & 0 \\
\hline $\mathrm{N}_{\mathrm{R}}$ & 7 & 0 & 0 & 0 & 3 & 0 & 10 & 0 & 4 \\
\hline $\mathrm{N}_{\mathrm{S}} \mathrm{r}$ & 0 & 0 & 0 & 0 & 0 & 0 & 7 & 0 & 3 \\
\hline $\mathrm{F}_{1}$ & 7 & 10 & 5 & 6 & 3 & 5 & 5 & 1 & 3 \\
\hline $\mathrm{F}_{2}$ & 1 & 4 & 3 & 2 & 1 & 1 & 1 & 1 & 2 \\
\hline $\mathrm{F}_{3}$ & 0 & 0 & 2 & 0 & 1 & 0 & 2 & 1 & 0 \\
\hline $\mathrm{H}^{\prime}$ & 2.73 & 3.64 & 3.18 & 3.43 & 3.00 & 1.54 & 3.08 & 2.63 & 2.09 \\
\hline $\mathrm{D}$ & 0.22 & 0.11 & 0.12 & 0.11 & 0.15 & 0.54 & 0.18 & 0.18 & 0.32 \\
\hline $\mathrm{S}_{\text {Chaol }}$ & 37.50 & 30.50 & 14.17 & 23.00 & 15.50 & 20.50 & 31.50 & 7.50 & 12.25 \\
\hline Var(S & 967.75 & 114.06 & 23.84 & 103.50 & 51.75 & 293.75 & 293.75 & 1.75 & 11.53 \\
\hline
\end{tabular}

The highest number of specimens was registered for females of the genus Hydropsyche, 128 in total, which represents almost $20 \%$ of all specimens captured during this investigation. Other species with relatively high abundance are: Silo piceus (Brauer, 1857) (76), Ithytrichia lamellaris Eaton, 1873 (66) and Psychomyia pusilla (Fabricius, 1781) (61) (Tab. 2). These three species altogether constitute more than $30 \%$ of all individuals collected. Twelve species were collected with fewer than five individuals. Moreover, out of these, six species were represented with a single individual: Philopotamus variegatus (Scopoli, 1763), Brachycentrus maculatus (Fourcroy, 1785), Annitella triloba Marinkovic-Gospodnetic, 1957, Stenophylax meridiorientalis Malicky, 1982, Crunoecia irrorata (Curtis, 1834), Adicella balcanica Botosaneanu \& Novak, 1965 and Mystacides niger (Linnaeus, 1758).

The number of eudominant and dominant species varies from 0 to 5 , with stations L3 and L8 having the highest number of eudominant species, and station L3 the highest number of dominant species (Tab. 3). Station L2 has the highest number of subdominant species (14). Station L1 has the highest number of recendent species (7). In all stations except two (L7 and L9) subrecendent species are completely missing. In total, the abundance of the eudominant species is the highest (451), while the abundance of subrecendent species is represented with 10 specimens only. The highest value of the Shannon-Wiener Index of diversity is registered in Station L2 and the lowest in Station L6, while the highest value of Simpson's Index was registered in L6 and the lowest in L2 and L4. There is no species present in all nine sampling stations (Tab. 2, Tab. 3). 
Tab. 4. Phenological information (first presence, last presence, peak abundance date and peak abundance) for observed species in the Llap River catchment and a total number of male and female specimens.

+ short flight period of two or less months; * long flight period of three or more months.

\begin{tabular}{|c|c|c|c|c|c|c|c|}
\hline \multirow[b]{2}{*}{ Taxa } & \multicolumn{2}{|c|}{$\begin{array}{l}\text { Number of } \\
\text { individuals }\end{array}$} & \multicolumn{5}{|c|}{ Seasonal presence } \\
\hline & $\mathbf{M}_{\bigcirc}^{\lambda}$ & $\mathbf{F}_{+}$ & $\begin{array}{c}\text { First } \\
\text { presence }\end{array}$ & Last presence & $\begin{array}{c}\text { Peak } \\
\text { abundance } \\
\text { date }\end{array}$ & $\begin{array}{c}\text { Peak } \\
\text { abundance }\end{array}$ & $\begin{array}{l}\text { Duration of } \\
\text { flight period } \\
\text { (months) }\end{array}$ \\
\hline Rhyacophila armeniaca * & 13 & 1 & 12 July & 08 September & 05 August & 8 & 3 \\
\hline Rhyacophila fasciata * & 16 & 9 & 15 June & 04 September & 08 July & 10 & 4 \\
\hline Rhyacophila loxias * & 9 & 1 & 16 June & 06 August & 06 August & 5 & 3 \\
\hline Rhyacophila nubila * & 8 & 7 & 19 June & 05 September & 05 September & 6 & 4 \\
\hline Rhyacophila obliterata* & 6 & 0 & 06 August & 12 November & 06 August & 4 & 4 \\
\hline Rhyacophila polonica + & 15 & 1 & 17 June & 09 July & 17 June & 14 & 2 \\
\hline Rhyacophila tristis + & 10 & 3 & 16 June & 10 July & 18 June & 12 & 2 \\
\hline Agapetus laniger + & 2 & 0 & 11 July & 11 July & 11 July & 2 & 1 \\
\hline Synagapetus iridipennis + & 5 & 0 & 19 June & 12 July & 12 July & 3 & 2 \\
\hline Hydroptila forcipata * & 3 & 37 & 08 July & 07 September & \begin{tabular}{|c|}
08 July \\
07 September \\
\end{tabular} & 15 & 3 \\
\hline Ithytrichia lamellaris + & 0 & 66 & 09 July & 07 August & 09 July & 64 & 2 \\
\hline Philopotamus montanus * & 6 & 2 & 15 June & 08 August & 15 June & 6 & 3 \\
\hline Philopotamus variegates + & 1 & 0 & 19 June & 19 June & 19 June & 1 & 1 \\
\hline Wormaldia occipitalis + & 5 & 1 & 17 June & 10 July & 17 June & 4 & 2 \\
\hline Hydropsyche instabilis * & 44 & 0 & 18 June & 09 August & 09 August & 26 & 3 \\
\hline Hydropsyche saxonica + & 2 & 0 & 08 July & 08 July & 08 July & 2 & 1 \\
\hline Hydropsyche sp. females * & 0 & 128 & 18 June & 05 September & 10 July & 81 & 4 \\
\hline Polycentropus excisus + & 0 & 2 & 06 August & 06 August & 06 August & 2 & 1 \\
\hline Lype reducta + & 3 & 2 & 15 June & 16 June & 15 June & 5 & 1 \\
\hline Psychomyia pusilla* & 8 & 46 & 17 June & 07 August & 08 July & 47 & 3 \\
\hline Tinodes rostocki ${ }^{*}$ & 5 & 13 & 19 June & 08 August & 09 July & 9 & 3 \\
\hline Tinodes unicolor + & 1 & 1 & 10 July & 10 July & 10 July & 2 & 1 \\
\hline Brachycentrus maculatus * & 1 & 2 & 18 June & 09 August & 18 June & 2 & 3 \\
\hline Drusus botosaneanui + & 5 & 6 & 08 September & 08 September & 08 September & 11 & 1 \\
\hline Halesus digitatus * & 1 & 27 & 07 September & 14 November & 07 September & 15 & 3 \\
\hline Potamophylax latipennis * & 4 & 15 & 11 July & 07 October & 06 September & 14 & 4 \\
\hline Annitella triloba + & 1 & 0 & 13 November & 13 November & 13 November & 1 & 1 \\
\hline Stenophylax meridiorientalis + & 0 & 1 & 08 September & 08 September & 08 September & 1 & 1 \\
\hline Silo piceus + & 9 & 67 & 15 June & 12 July & 12 July & 74 & 2 \\
\hline Lepidostoma basale + & 2 & 7 & 16 June & 08 July & 16 June & 5 & 2 \\
\hline Crunoecia irrorata + & 1 & 0 & 07 August & 07 August & 07 August & 1 & 1 \\
\hline Adicella balcanica + & 1 & 0 & 12 July & 13 July & 12 July & 1 & 1 \\
\hline Athripsodes bilineatus + & 4 & 0 & 11 July & 06 August & 11 July & 3 & 2 \\
\hline Mystacides nigra + & 1 & 0 & 10 July & 10 July & 10 July & 1 & 1 \\
\hline Odontocerum hellenicum * & 6 & 2 & 16 June & 07 August & 16 July & 5 & 3 \\
\hline Oecismus monedula* & 7 & 0 & 18 June & 08 August & 09 July & 5 & 3 \\
\hline Sericostoma flavicorne + & 1 & 1 & 15 June & 08 July & $\begin{array}{l}15 \text { June, } \\
\text { 08 July }\end{array}$ & 1 & 2 \\
\hline
\end{tabular}


A short duration of the flight period of two months or less, was observed for 23 species and long duration of the flight period of more than two months was observed for 14 species (Tab. 4). Not a single species is present continuously throughout the whole sampling period. Eleven species were found during one month only (Tab. 4). A four-month duration of flight, which is the longest period observed during this investigation, was registered in the following three species: Rhyacophila fasciata Hagen, 1859, Rhyacophila nubila Zetterstedt, 1840, Potamophylax latipennis (Curtis, 1834) and also female specimens of the genus Hydropsyche. Three species were observed to have flight activity only in spring (Philopotamus variegatus, Wormaldia occipitalis (Pictet, 1834) and Lype reducta (Hagen, 1868)), 11 species only in summer (Agapetus laniger Pictet, 1834, Ithytrichia lamellaris, Hydropsyche saxonica McLachlan, 1884, Polycentropus excisus Klapalek, 1894, Drusus botosaneanui Kumanski, 1968, Stenophylax meridiorientalis, Crunoecia irrorata, Adicella balcanica, Athripsodes bilineatus (Linnaeus, 1758), Mystacides niger and Oecismus monedula (Hagen, 1859)) and only two species were observed with a flight period only in autumn (Annitella triloba and Halesus digitatus (von Paula Schrank, 1781)).

\section{DISCUSSION}

As a result of this investigation, new occurrence localities for several endemic and rare species were registered, constituting an expansion of the known distribution range of these species. They are: Synagapetus iridipennis McLachlan, 1879, Ithytrichia lamellaris, Crunoecia irrorata, Polycentropus excisus, Rhyacophila loxias Schmid, 1970, Drusus botosaneanui, Annitella triloba, Odontocerum hellenicum Malicky, 1972 and Adicella balcanica. The last five mentioned species are endemics of the Balkan Peninsula restricted to a limited number of localities. The genus Ithytrichia Eaton, 1873, and Ithytrichia lamellaris are new for the Kosovo caddisfly fauna, expanding greatly the known distribution of this genus in the Balkan Peninsula. Hitherto, two species from this genus had been recorded on the Balkan Peninsula, Ithytrichia bosniaca Murgoci, Botnariuc \& Botosaneanu, 1948 and I. lamellaris, both with only a few records (Neu et al., 2018). Ithytrichia lamellaris was previously reported from Slovenia, Croatia and Serbia (URBAnIČ, 2001; ĆuKušıć et al., 2017; StojAnović, 2015), thus, records from the remaining countries in the region are still lacking. This is the fourth known species of the family Hydroptilidae from Kosovo (IвRAHIMI et al., 2014b). I. lamellaris can be found almost in all river segments except eucrenal and hypocrenal zones with larvae preferring macrophytes as a substrate and belonging to the feeding category of grazers/scrapers (GRAF et al., 2008). It has been reported to have a flight period from June to September (KuMANSKI, 1985) which is also in line with the current investigation. It is interesting to note the high abundance of I. lamellaris at sampling station S9 during this investigation, which was probably due to the favourable conditions at this locality, such as the presence of macrophytes and mosses throughout this segment of the river and the high amount of food for grazers/scrapers. This level of abundance was not observed in other investigations in the Balkan Peninsula and Southeastern Europe where I. lamellaris has been found (e.g. URBANič, 2001; ĆuKUšıć et al., 2017; Stojanović, 2015). Crunoecia irrorata was also found for the first time in Kosovo during this investigation. Although this species is known from most parts of Europe, it has been rarely sampled in the Balkan Peninsula (MaLicky, 2018). Previously only one species of this genus was known from Kosovo, Crunoecia bosniaca Marinkovic-Gospodnetic, 1970 (Marinković-Gospodnetić, 1980), which is an endemic species of the Balkan Peninsula, but has not been reported from Kosovo subsequently. C. irrorata can be found mostly in eucrenal and hypocrenal zones (GrAf et al., 2008), which was also the case during this 
investigation, where it was only found in the upper reach of the Llap River. Larvae of this species prefer madicol habitats and feed on woody debris, fallen leaves, plant tissue and at a lesser degree as predators (GRAF et al., 2008). The flight period of this species observed during our investigation is in line with the previous data (GrAF et al., 2008). Apparently our finding of this species represents the first occurrence data for Ecoregion 6, Hellenic Western Balkans.

The highest number of species and the highest values of diversity indices are found in the upper reaches (Kaqandoll River L7 and the Murgull River L2) of the two biggest tributaries that create the Llap River, in consequence of the richness of different habitats suitable for caddisflies composed by stones of different sizes, gravel, fallen leaves and other material of plant origin. The lowest number of species and the lowest values of diversity indices were found at L6 and L8, the first one located inside the inhabited area and the second one located at the spring area of the Llap River tributary. The inhabited areas surrounding the midstream and downstream reaches of the Llap River discharge their sewage effluents and effluents from agricultural activities directly into the river. Most of the caddisfly species are vulnerable to this kind of organic load into their habitat. In this regard, adult caddisfly assemblages serve as a strong indicator of ecological integrity and quality, even though in routine water quality assessments larvae have mostly been used (e.g. Schmera, 2003; Sмith et al., 2002; Stanić-Koštroman et al., 2012). By employing a variety of collecting methods and extending the time of collection efforts, the number of known species in the upper and middle reaches of the Llap River will definitely be increased. A large number of singletons, doubletons and tripletons per stations are a strong indicator of a much richer caddisfly fauna in the investigation area than was established during this research. In station L2, for example, 10 singletons are registered and the medium value of singletons per station is 5 , which is a rather high value and a reliable indicator for the richness of caddisfly fauna of the Llap River. The species richness estimator ( $\mathrm{CHAO} \& \mathrm{CHIU}, 2016)$ predicts the highest number of unrecorded species in stations located in the upper reaches of the river and the lowest numbers of unrecorded species in the middle reaches of river. A higher number of species is expected in the Llap River catchment as predicted by this indicator index, considering the richness of habitats in the area and short period of sampling during this investigation. Although this investigation contributes to knowledge of the caddisfly composition of the Llap River catchment, the number of known caddisfly species from this area is still low, which makes impossible any qualitative and ecological comparison of this river catchment with other catchments in Kosovo and elsewhere in the Balkan Peninsula. For example during this investigation an endemic species of this river catchment, Drusus dardanicus Ibrahimi, Kučinić \& Vitecek, 2015, was not found. Higher sampling efforts, especially in spring area habitats as well as lower reaches, are necessary to have complete picture of the caddisfly fauna composition of this river catchment. Beside the abovementioned two first records for caddisflies of Kosovo from the Llap River catchment, which are unique for this catchment in Kosovo, the species Adicella balcanica. which was found during this investigation, is currently known in Kosovo only from this river catchment. Other endemic or rare species found during this investigation, even if only occasionally, are however found in other areas in Kosovo as well, such as Bjeshkët e Nemuna and Sharr Mountains (IвRAHIмі et al., 2012a; 2014a).

There is a clear pattern of seasonality in the abundance and number of species. The largest number of species and specimens was collected during the warmer months. In total, 31 species and 551specimens were collected during the summer period, 20 species 
and 82 specimens were collected during the spring period and only 3 species with 20 specimens were collected during the autumn months. Although most of the rare and endemic species were collected during the first part of the summer period, some other species were only found during the spring and autumn, thus making sampling during the whole year necessary in cases when the qualitative aspect of the investigation is the major goal of the research, as proven in other similar research works (IвRAнiмi et al., 2012a; 2012b; 2014a; 2014b).

This study is a contribution to a baseline taxonomic composition and ecological features of caddisflies in Kosovo and South-eastern Europe. Many previous investigations in the area were only focused on certain taxonomic issues (e.g. GAsHi et al., 2015; MALICKY, 1986, 1999; Marinković-Gospodnetić 1975, 1980; OlÁH, 2010; OláH et al., 2013a; 2013b; Pongrácz, 1923; Previšić et al., 2014; Ibrahimi et al., 2012a, 2012b, 2013, 2014a, 2014b, 2015; IвrAhimi \& GAshi, 2008). The continuous degradation of rivers and streams in Kosovo and the Balkan Peninsula during the last few years (e.g. Gashi et al., 2015) makes such kind of baseline organismal biodiversity study a necessary tool in advocating for the conservation and protection aspects of freshwater ecosystems (SHELDON \& JEWEW, 1967).

\section{ACKNOWLEDGEMENT}

We would like to thank Ana Previšić and the second reviewer, whose comments significantly improved this manuscript.

Received May 17, 2018

\section{REFERENCES}

Corbet, P.S., 1964: Temporal patterns of emergence in aquatic insects. The Canadian Entomologist 96, 264-279.

Снао, А. \& Снiu, С. H., 2016: Species richness: estimation and comparison. Wiley StatsRef: Statistics Reference Online 1-26.

Čukušić, A., Ćuk, R., Previšić, A., Podnar, M., Delić, A. \& Kučinić, M., 2017: DNA barcoding and first records of two rare Adicella species (Trichoptera: Leptoceridae) in Croatia. Biologia 72/7, 796-806.

DeWalt, R.E., Stewart, K.W., Moulton, S.R. \& Kennedy, J.H., 1994: Summer emergence of mayflies, stoneflies and caddisflies from a Colorado Mountain Stream. The Southwest Naturalist 39, 249-256.

Drozd, P., 2010: ComEcoPaC - Community Ecology Parameter Calculator. Version 1. <http://prf.osu.cz/ kbe/dokumenty/sw/ComEcoPaC/ComEcoPaC.xls accessed at: 2017.08.13>.

Gashi, A., Ibrahimi, H., Grapci-Kotori, L., Sejdiu, N. \& Bislimi, K., 2015: New Records of Drusus siveci Malicky, 1981 (Trichoptera, Limnephilidae, Drusinae) from the Balkan Peninsula, with Ecological Notes. Acta Zoologica Bulgarica 67, 259-264.

Graf, W., Murphy, J., Dahl, J., Zamora-Muñoz, C. \& López-Rodríguez, M.J., 2008 :Volume 1 - Trichoptera. In: Schmidt-Kloiber, A. \& Hering, D. (Eds) Distribution and Ecological Preferences of European Freshwater Organisms. Sofia, Moscow: Pensoft Publishers.

GRANT, P.R. \& MACKAY, R.J., 1969: Ecological separation of systematically related stream insects. Canadian Journal of Zoology 47, 691-694.

Houghton, D.C, 2002: Biodiversity of Minnesota caddisflies (Insecta: Trichoptera). PhD, Univeristy of Minnesota, Minnesota, United States of America.

Iвrahimi, H. \& Gashi, A., 2008: State of knowledge of investigations on Trichoptera larvae in Kosova. Ferrantia 55, 70-73.

Ibrahimi, H., Gashi, A., Bilalli, A., Musliu, M., Grapci Kotori, L. \& Etemi-Zhushi, F., 2014a: Three new country records from the genus Limnephilus Leach, 1815 (Trichoptera: Limnephilidae) from the Republic of Kosovo. Biodiversity Data Journal (2), e4140.

Ibrahimi, H., Gashi, A., Grapci-Kotori, L., Bilalli, A., Musliu, M. \& Etemi-Zhushi, F., 2015: First record of Mesophylax aspersus (Rambur, 1842) from the Republic of Kosovo (Trichoptera Limnephilidae). Biodiversity Journal 6, 3-6. 
Ibrahimi, H., Gashi, A., Grapci-Kotori, L. \& Kučinić, M., 2013: First records of the genus Micropterna Stein, 1873 (Insecta: Trichoptera) in Kosovo with distributional and ecological notes. Natura Croatica 22, 147-155.

Ibrahimi, H., Kučinić, M., Gashi, A. \& Grapci Kotori, L., 2014b: Trichoptera Biodiversity of the Aegean and Adriatic Sea basins in Kosovo. Journal of Insect Science 14, 1-8.

Ibrahimi, H., Kučinić, M., Gashi, A. \& Grapci-Kotori, L., 2012a: The caddisfly fauna (Insecta, Trichoptera) of the rivers of the Black Sea basin in Kosovo with distributional data for some rare species. ZooKeys 182, 71-85.

Ibrahimi, H., Kučinić, M., Gashi, A., Grapci-Kotori, L., VučKović, I. \& Cerjanec, D., 2012b: The genus Rhyacophila Pictet, 1873 (Insecta: Trichoptera) in Kosovo. Aquatic Insects 34, 23-31.

Kumanski, K., 1985: Trichoptera, Annulipalpia. Fauna Bulgarica 15. Bulgaria: Bulgarska Akademi na Naukite.

KumAnski, K., 1988: Trichoptera, Integripalpia. Fauna Bulgarica 19. Bulgaria: Bulgarska Akademi na Naukite.

Malicky, H., 1986: Beschreibung von vier neuen KöcherfliegenArten aus der Turkei und aus Jugoslawien (Trichoptera). Opus Zool Flumin 4, 1-7.

Malicky, H., 1999: Bemerkungen uber die Verwandtschaft von Hydropsyche pellucidula Curtis (Trichoptera, Hydropsychidae). Linzer Biologische Beitraege 31(2), 803-821.

Malicky, H., 2004: Atlas of European Trichoptera. 2nd Edition. Netherlands: Springer.

Malicky, H., 2018: Trichoptera. - In DE Jong H. (ed.), Fauna Europaea: Trichoptera. Version 2.4, http:// www.faunaeur.org (Accessed 27 July 2018).

Marinković-Gospodnetić, M., 1975: Fauna Trichoptera SR Srbija. Zbornik radova o entomofauni Srbije 1, 219-236.

Marinković-Gospodnetić, M., 1980: Fauna Trichoptera SR Srbija. Zbornik radova o fauni Srbije 1, 71-84.

Morse, J.C., 2017: Trichoptera World Checklist Database Search, http://entweb.clemson.edu/database/ trichopt (Accessed January 19, 2017).

Neu, P. J., Malicky, H., Graf, W. \& Schmidt-Kloiber, A., 2017: Distributional Atlas of European Trichoptera, ConchBooks, 891pp.

Olá́, J., 2010: New species and new records of Palearctic Trichoptera in the material of the Hungary Natural History Museum. Annales Historico-Naturales Musei Nationalis Hungarici 102, 65-117.

Oláh, J., Andersen, T., Chvojka, P., Coppa, G., Graf, W., Ibrahimi, H., Previšić, A. \& Valle, M., 2013a: The Potamophylax nigricornis group (Trichoptera, Limnephilidae): resolution of phylogenetic species by fine structure analysis. Opuscula Zoologica Budapest 44(2), 167-200.

Olá́, J., Ibrahimi, H. \& Kovács, T., 2013b: The genus Chaetopteroides (Trichoptera, Limnephilidae) revised by fine structure analysis of parameres. Folia Historico Naturalia Musei Matraensis 37, 93-108.

Pongrácz, S., 1923: Recésszárnyúak. Neuropteroiden. In: Csiki Erno Állattani Kutatásai Albániában. Explorationes zoologicae ab E. Csiki in Albania peractae. IX. A. Magyar Tudományos Akadémia Balkán-Kutatásainak Tudományos Erdményei 1, 160-166.

Previšić, A., Schnitzler, J., Kučinić, M., Graf, W., Ibrahimi, H., Kerovec, M. \& Pauls, S., 2014: Micro-Scale Vicariance and Diversification of Western Balkan Caddisflies Linked to Karstification. Freshwater Science 33, 250-262.

Schmera, D., 2003: Light trap-collected caddisfly (Insecta: Trichoptera) assemblages reflect altitude. Community Ecology, 4(2), 233-236.

Smith, B. J., Collier, K. J., \& Halliday, N. J., 2002: Composition and flight periodicity of adult caddisflies in New Zealand hill-country catchments of contrasting land use. New Zealand Journal of Marine and Freshwater Research, 36, 863-878

Sheldon, A.L. \& Jewew, S.G., 1967: Stonefly emergence in a Sierra Nevada stream. The Pan Pacific Entomologist 43, 1-8.

Stanić-Koštroman, S., Kučinić, M., Kolobara, A., Škobić, D., Knezović, L. \& Durbešić, P., 2012: Ligh trapped caddisflies (Insecta: Trichoptera) as indicators of the ecological integrity of the Listica River, Bosnia and Herzegovina. Entomologica Croatica 16, 21-36.

Stojanović, K., Žıvić, I., Žnidaršić, T. K., Živić, M., Žunič, M., Simić, V. \& Marković, Z., 2015: Ithytrichia Eaton, 1873 (Hydroptilidae: Trichoptera): A genus new for the entomofauna of Serbia. Entomological News 125(1), 52-62.

Tischlen, W., 1949: Grundzüge der terrestrischen Tierökologie. Braunschweig, Friedrich Vieweg und Sohn.

Urbanič, G., 2001: Contribution to the knowledge of caddisflies (Trichoptera) of the Reservoir Ledavsko Jezero, NE Slovenia. Acta Entomologica Slovenica 9(2), 129-134. 


\title{
SUMMARY
}

\section{The caddisfly fauna (Insecta: Trichoptera) of the Llap River catchment, Republic of Kosovo}

\author{
H. Ibrahimi \& N. Sejdiu
}

Adult caddisfly specimens were collected with entomological nets and UV pyramid type light traps during the period May 2013 - November 2013, once per month at nine sampling stations in the Llap River catchment in Kosovo. During this investigation, a total of 651 adult specimens (446 females and 204 males) were collected, belonging to 37 species, 22 genera and 14 families. The highest number of species during this investigation was found in the upper reaches (the Kaqandoll River L7 and the Murgull River L2) of the two biggest tributaries which form the Llap River, resulting from the richness of different habitats suitable for caddisflies. The lowest number of specimens was found at L6 and L8, the first one located inside the inhabited area and the second one located at the spring area of the Llap River tributary. There is a clear pattern of seasonality in abundance and number of species. The highest number of species and specimens was collected during the warmer months.

The genus Ithytrichia, which is according to the current knowledge rather rare in the Balkan Peninsula, is reported for the first time from Kosovo. Two species are first records for the Kosovo caddisfly fauna: Crunoecia irrorata and Ithytrichia lamellaris. Previously, both species had been rarely sampled in South-eastern Europe. Several other endemic or rare species of the Balkan Peninsula have been collected during this investigation such as: Rhyacophila loxias, Synagapetus iridipennis, Polycentropus excisus, Drusus botosaneanui, Annitella triloba, Odontocerum hellenicum and Adicella balcanica. 